Article

\title{
Thermochemical Conversion of Biomass in the Presence of Molten Alkali-Metal Carbonates under Reducing Environments of $\mathrm{N}_{2}$ and $\mathrm{CO}_{2}$
}

\author{
Tahereh Jalalabadi, Behdad Moghtaderi and Jessica Allen * \\ School of Chemical Engineering, University of Newcastle, Callaghan, NSW 2308, Australia; \\ tahereh.jalalabadi@uon.edu.au (T.J.); Behdad.Moghtaderi@newcastle.edu.au (B.M.) \\ * Correspondence: j.allen@newcastle.edu.au; Tel.: +612-40-339-359
}

Received: 15 September 2020; Accepted: 12 October 2020; Published: 15 October 2020

check for updates

\begin{abstract}
The impact of $\mathrm{N}_{2}$ and $\mathrm{CO}_{2}$ atmospheres on the interaction between Eucalyptus pilularis biomass and a ternary molten carbonate eutectic $\left(\mathrm{Li}_{2} \mathrm{CO}_{3}: \mathrm{Na}_{2} \mathrm{CO}_{3}: \mathrm{K}_{2} \mathrm{CO}_{3}\right)$ has been investigated at $600{ }^{\circ} \mathrm{C}$ and $900{ }^{\circ} \mathrm{C}$. For lower temperature conversion under $\mathrm{CO}_{2}$, prevention of volatile release in the eutectic treated biomass is slightly higher than under $\mathrm{N}_{2}$ injection; however, similar bubble-shaped morphology of the remnant char is observed under both carrier gases. By increasing the temperature to $900{ }^{\circ} \mathrm{C}$ under $\mathrm{CO}_{2}$, the reverse Boudouard reaction begins to consume carbon fuel, while molten carbonate gasification also accelerates the reaction to a lower temperature set point (shifted from $\sim 735^{\circ} \mathrm{C}$ to $\sim 640{ }^{\circ} \mathrm{C}$ ). The mass loss of carbonate under $\mathrm{CO}_{2}$ and $\mathrm{N}_{2}$ at $900{ }^{\circ} \mathrm{C}$ is 0 (negligible) and $18 \mathrm{wt} . \%$, respectively. In the absence of carbon particles, the decomposition of carbonate to $\mathrm{M}_{2} \mathrm{O}(\mathrm{l})$ and $\mathrm{CO}_{2}(\mathrm{~g})$, as well as molten salt vaporization, are the sole potential routes of weight loss in an inert gas. Previous observations of biomass and eutectic mixture thermochemical conversion under $\mathrm{N}_{2}$ have suggested carbon/carbonate gasification is dominant at elevated temperatures, with production of $\mathrm{CO}$ expected. However, analysis of gas chromatography (GC) suggests that carbon/carbonate gasification is the weaker pathway by producing only $7 \mathrm{vol} \%$ of $\mathrm{CO}$, compared with molten carbonate decomposition with 27 vol. $\% \mathrm{CO}_{2}$ emission for this system.
\end{abstract}

Keywords: slow pyrolysis; Boudouard reaction; carbonate gasification; ternary eutectic; biomass

\section{Introduction}

Thermochemical conversion is considered the most ancient procedure in biomass utilization. The reaction pathway categorized is based on temperature and oxidizing agent. From this perspective, pyrolysis takes place in the absence of oxygen (often under $\mathrm{N}_{2}$ or Ar environments), combustion takes place in a full oxidizing environment (typically air with excess oxygen), and gasification is carried out under a partial oxidizing environment (often mixtures of air with $\mathrm{CO}_{2}$ or steam) [1]. For decades, researchers have investigated the benefits of biomass gasification and pyrolysis in comparison with a more tradition pathway of combustion [2-7].

Pyrolysis of biomass heavily depends on heating rate (classified between slow and fast) [8,9], which produces biogas (mainly, $\mathrm{CO}, \mathrm{CO}_{2}, \mathrm{H}_{2}$, and $\mathrm{CH}_{4}$ ), bio-oil (brown greasy mixture of non-condensable volatiles), and bio char (solid carbonaceous residue) [10-12]. During pyrolysis of biomass, each inherent component of feedstock (such as hemicellulose, cellulose, and lignin) decomposes through its own individual pathway at different operational temperature ranges (from $\sim 200{ }^{\circ} \mathrm{C}$ for hemicellulose to approximately $600{ }^{\circ} \mathrm{C}$ for lignin) $[13,14]$. In contrast with pyrolysis in an inert gaseous environment, endothermic and heterogeneous gasification of biomass under steam and $\mathrm{CO}_{2}$ provides well known paths of steam gasification (reaction-4) [15] and Boudouard conversion (reaction-5) [7] with production of $\mathrm{CO}$ and $\mathrm{H}_{2}$. Key reactions in biomass gasification are listed in Table 1. 
Table 1. Oxidation and gasification reactions in biomass thermal conversion [1].

\begin{tabular}{|c|c|c|}
\hline Number & Reaction & $\Delta \mathbf{H}^{\mathbf{o}} \mathbf{R}$ \\
\hline \multicolumn{3}{|c|}{ Oxidation Reactions } \\
\hline 1 & $\mathrm{C}+\frac{1}{2} \mathrm{O}_{2} \rightarrow \mathrm{CO}$ & $-111(\mathrm{MJ} / \mathrm{kmol})$ \\
\hline 2 & $\mathrm{CO}+\frac{1}{2} \mathrm{O}_{2} \rightarrow \mathrm{CO}_{2}$ & $-283(\mathrm{MJ} / \mathrm{kmol})$ \\
\hline 3 & $\mathrm{H}_{2}+\frac{1}{2} \mathrm{O}_{2} \rightarrow \mathrm{H}_{2} \mathrm{O}$ & $-242(\mathrm{MJ} / \mathrm{kmol})$ \\
\hline \multicolumn{3}{|c|}{ Gasification Reactions } \\
\hline 4 & $\begin{array}{l}\mathrm{C}+\mathrm{H}_{2} \mathrm{O} \rightarrow \mathrm{CO}+\mathrm{H}_{2} \\
\text { (Water-Gas reaction) }\end{array}$ & $+131(\mathrm{MJ} / \mathrm{kmol})$ \\
\hline 5 & $\begin{array}{c}\mathrm{C}+\mathrm{CO}_{2} \rightarrow 2 \mathrm{CO} \\
\text { (Boudouard reaction) }\end{array}$ & $+172(\mathrm{MJ} / \mathrm{kmol})$ \\
\hline 6 & $\begin{array}{c}\mathrm{C}+2 \mathrm{H}_{2} \rightarrow \mathrm{CH}_{4} \\
\text { (Methanation reaction) }\end{array}$ & $-75(\mathrm{MJ} / \mathrm{kmol})$ \\
\hline 7 & $\begin{array}{c}\mathrm{CO}+\mathrm{H}_{2} \mathrm{O} \rightarrow \mathrm{CO}_{2}+\mathrm{H}_{2} \\
\text { (Water-Gas-Shift reaction) }\end{array}$ & $-41(\mathrm{MJ} / \mathrm{kmol})$ \\
\hline 8 & $\begin{array}{c}\mathrm{CH}_{4}+\mathrm{H}_{2} \mathrm{O} \rightarrow \mathrm{CO}+3 \mathrm{H}_{2} \\
\text { (Methane-Steam reforming) }\end{array}$ & $+206(\mathrm{MJ} / \mathrm{kmol})$ \\
\hline
\end{tabular}

$\mathrm{CO}_{2}$ gasification is thermodynamically favored at temperatures above $680^{\circ} \mathrm{C}$ (a similar temperature to steam gasification [16]). The environmentally friendly route of $\mathrm{CO}_{2}$ consumption, through solitary $\mathrm{CO}$ production via Boudouard reaction, counts as an advantage for commercial scaled-up $\mathrm{CO}_{2}$ gasification plants compared with steam gasification [11]. To understand pyrolysis and $\mathrm{CO}_{2}$ gasification routes of biomass, different groups have investigated the effect of variables, such as the nature of feedstock $[7,17,18]$, the catalytic role of chemical additives, such as alkaline metal salts [19-24], hydroxides [25,26], chlorides $[27,28]$, and the heating rate to the final working temperature $[9,22,24,29,30]$. However, during pyrolysis up to $680^{\circ} \mathrm{C}$ (known gasification starting temperature), the major reaction regime is devolatilization and primary char production, while gasification is an extension of pyrolysis at a higher temperature when conducted with carbon dioxide $\left(>\sim 680^{\circ} \mathrm{C}\right)$ [12]. Although there are a significant number of reports in addressing biochar modification under $\mathrm{CO}_{2}$ and $\mathrm{N}_{2}$ [29-31], this has mainly been done in the absence of chemical additives. For example, in a recent work, Kim et al. [31] reported char modification resulting from different types of feedstock (such as cellulose, lignin, xylan, grass, and oak wood) during both slow and fast heating rates up to $680^{\circ} \mathrm{C}$, avoiding Boudouard gasification (reaction-5). Based on their findings, carrier gas impact on remnant char surface area is highly dependent on input feedstock, and the notable improvement of $\mathrm{BET}_{\text {sur }}$ results demonstrated large variation in outcomes of oak wood $\left(231.15 \mathrm{~m}^{2} \mathrm{~g}^{-1}\right.$ under $\mathrm{N}_{2}$ and $463.58 \mathrm{~m}^{2} \mathrm{~g}^{-1}$ under $\left.\mathrm{CO}_{2}\right)$ with less impact on cellulose $\left(507.53 \mathrm{~m}^{2} \mathrm{~g}^{-1}\right.$ under $\mathrm{N}_{2}$ and $506.94 \mathrm{~m}^{2} \mathrm{~g}^{-1}$ under $\mathrm{CO}_{2}$ ). Senneca's group [29] also acknowledged the impact of a gaseous atmosphere on walnut shell thermochemical conversion with ramping rate $\left(5\right.$ to $\left.20^{\circ} \mathrm{C} / \mathrm{min}\right)$ up to $900{ }^{\circ} \mathrm{C}$, the outcome being a higher amount of $\mathrm{O} / \mathrm{C}$ and $\mathrm{H} / \mathrm{C}$ for char prepared under $\mathrm{N}_{2}$ compared to $\mathrm{CO}_{2}$, which makes it more reactive in combustion.

However, the impact of carrier gas while using chemical additives, such as alkaline carbonates, during biomass conversion is not well understood. The high thermal expected stability of molten carbonate and its catalytic influence on the Boudouard gasification reaction attracts many researchers to broadly explore biomass gasification modified by this additive $[3,23,32,33]$.

However, the decomposition of carbonate salts (reaction-9, where M represents alkali-metals Li, $\mathrm{Na}$, or $\mathrm{K}$ ) is suggested by other researchers, particularly above $700{ }^{\circ} \mathrm{C}$ [34-39].

$$
\mathrm{M}_{2} \mathrm{CO}_{3} \rightarrow \mathrm{M}_{2} \mathrm{O}+\mathrm{CO}_{2}(\text { Reaction -9) }
$$


It is observed that molten carbonate displays negligible mass loss under $\mathrm{CO}_{2}$ compared with inert gas $\left(\mathrm{Ar}, \mathrm{N}_{2}\right)$ and air injection. Alongside molten carbonate chemical decomposition, some studies have also suggested vaporization of carbonate at high temperatures $[19,22,40]$.

In the presence of carbon fuel, there is an additional route of carbonate consumption under $\mathrm{N}_{2}$, which is the result of its reaction with carbon particles. Above $700{ }^{\circ} \mathrm{C}$, reaction-10 takes place to generate $\mathrm{M}_{2} \mathrm{O}$ and $\mathrm{CO}$, which is known as carbon/carbonate gasification [34,41] or carbothermal reduction [39].

$$
\mathrm{M}_{2} \mathrm{CO}_{3}+\mathrm{C} \rightarrow \mathrm{M}_{2} \mathrm{O}+2 \mathrm{CO}(\text { Reaction - 10) }
$$

In a carefully designed study, Kopyscincki et al. [22] investigated the gaseous output of this reaction with major emission of $\mathrm{CO}$ from reaction- 10 for acid washed coal conversion after addition of $\mathrm{K}_{2} \mathrm{CO}_{3}$ under both $\mathrm{CO}_{2}$ and $\mathrm{N}_{2}$ up to $800{ }^{\circ} \mathrm{C}$.

To lower the melting point of alkali-metal carbonate additives, combining salts with different ratios is favored, specifically in high temperature fuel cell technology [42-44]. Exploration of binary compositions of carbonate $[40,45]$ or ternary eutectic [46-49] with lower melting points have been used extensively. Currently, there is a lack of precise information on a ternary molten carbonate interaction with carbon materials, such as biomass, under $\mathrm{N}_{2}$ and $\mathrm{CO}_{2}$, and separating the influence of potential reaction pathways has not been achieved to date.

The objective of this work is to explore the impact of injected gas $\left(\mathrm{N}_{2}\right.$ vs. $\left.\mathrm{CO}_{2}\right)$ on thermochemical conversion of woody biomass mixed with molten carbonate $\left([\mathrm{LiNaK}]_{2}\left(\mathrm{CO}_{3}\right)\right)$ with a slow heating rate $\left(5^{\circ} \mathrm{C} / \mathrm{min}\right.$ ) from ambient temperatures to two different higher heating temperatures ( $\mathrm{HHT}$ at $600{ }^{\circ} \mathrm{C}$ and $900^{\circ} \mathrm{C}$ ). The weight losses of all treated and untreated samples were recorded by thermogravimetric analysis (TGA) and by measuring the amounts of $\mathrm{CO}$ and $\mathrm{CO}_{2}$ emission with inline gas chromatography (GC).

\section{Materials and Methodology}

The Eucalyptus Pilularis woody biomass of our previous study [19] with average particle size range $(75-150 \mu \mathrm{m})$ was applied in this work and the ternary eutectic contained a mole percentage mixture of $\mathrm{Li}_{2} \mathrm{CO}_{3}: 43.5 \%, \mathrm{Na}_{2} \mathrm{CO}_{3}: 31.5 \%$, and $\mathrm{K}_{2} \mathrm{CO}_{3}: 25 \%$ with a melting point $\left(\sim 400{ }^{\circ} \mathrm{C}\right)$. This particle size range provided good particle contact between salts and biomass prior to salt reaching the molten state. All samples were dried in the oven $\left(110^{\circ} \mathrm{C}\right)$ overnight and mixed with a $50 \mathrm{wt} . \%$ impregnation ratio. For each experiment, $50 \mathrm{mg}$ of dried sample was loaded in an alumina crucible with a platinum handle (inner diameter: $15 \mathrm{~mm}$; height: $10 \mathrm{~mm}$ ) and placed inside a Rubotherm high pressure TGA (HP-TGA). Both gasification and pyrolysis were run with a heating rate of $5{ }^{\circ} \mathrm{C} / \mathrm{min}$ under $100 \mathrm{~mL} / \mathrm{min}$ of selected gases, followed by $120 \mathrm{~min}$ of isothermal treatment at two HHT $\left(600^{\circ} \mathrm{C}\right.$ and $900^{\circ} \mathrm{C}$ ). For lower deviation of results, each experiment was repeated three times with a standard error recorded. For biomass thermochemical conversion tests at $900{ }^{\circ} \mathrm{C}$, gas analysis of $\mathrm{CO}$ and $\mathrm{CO}_{2}$ emission was measured, where the Rubotherm HP-TGA outlet was connected to an Agilent 490 micro gas chromatograph (GC), which contains two columns and two thermal conductivity detectors (TCDs).

Additionally, after washing samples with hot distilled water $\left(80^{\circ} \mathrm{C}\right.$, details explained in [19]), the morphology of prepared chars from different types of injection was carried out via scanning electron microscopy (SEM) on a Ziess Sigma VP FESEM.

For further experiments, the char of biomass was produced in a horizontal tube furnace CHY- 1200 (Model: T1250S) under $\mathrm{N}_{2}(100 \mathrm{~mL} / \mathrm{min})$ via slow pyrolysis $\left(5^{\circ} \mathrm{C} / \mathrm{min}\right)$ to $600{ }^{\circ} \mathrm{C}$ and $2 \mathrm{~h}$ isothermal condition before cooling to an ambient temperature.

Naming conventions for a sample references its input condition to the test as raw biomass (Bio) or biomass char (Char), treated or untreated by carbonate (Bio indicates untreated and Bio50 expresses mixture with $50 \mathrm{wt} . \%$ of eutectic, as does Char50), and whether the test was completed under $\mathrm{N}_{2}$ or $\mathrm{CO}_{2}\left(\right.$ Bio50- $\mathrm{N}_{2}$, Bio50- $-\mathrm{CO}_{2}$, Char50- $\mathrm{N}_{2}$ and Char50- $\left.\mathrm{CO}_{2}\right)$. 


\section{Results}

\subsection{Thermochemical Conversion under $\mathrm{N}_{2}$ vs. $\mathrm{CO}_{2}$ at Low $\mathrm{HHT}\left(600^{\circ} \mathrm{C}\right)$}

The primary results of biomass conversion under $\mathrm{N}_{2}$ and $\mathrm{CO}_{2}$ at $600{ }^{\circ} \mathrm{C}$ are illustrated in Figure 1 . As there are no changes during $2 \mathrm{~h}$ isothermal tests at $600{ }^{\circ} \mathrm{C}$, only $15 \mathrm{~min}$ of isothermal results are presented, with an initial temperature above $200{ }^{\circ} \mathrm{C}$. Mass loss change versus time for untreated biomass (Bio) under $\mathrm{N}_{2}$ and $\mathrm{CO}_{2}$ show narrow deviation with only slight further devolatilization above $350{ }^{\circ} \mathrm{C}$ under $\mathrm{CO}_{2}$ compared to $\mathrm{N}_{2}$ (Figure $1 \mathrm{~A}$ ). This is in agreement with previous findings for modification of biomass char under $\mathrm{CO}_{2}$ without any additives $[29,31]$, with low overall impact on solid and liquid products, in contrast with effects reported about coal [50].

(A)

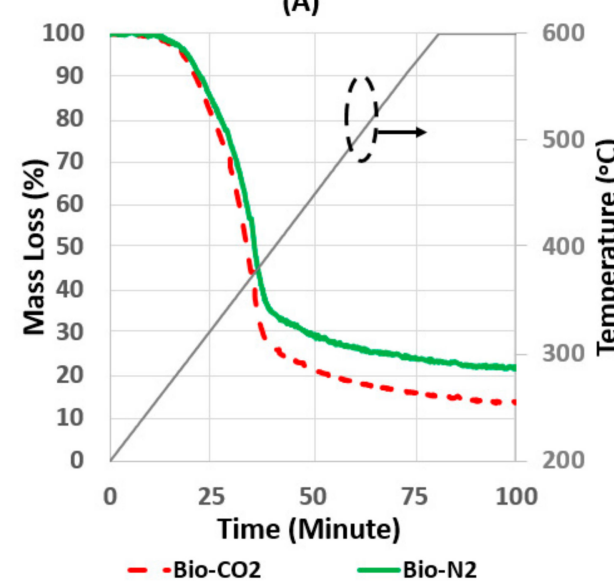

(C)

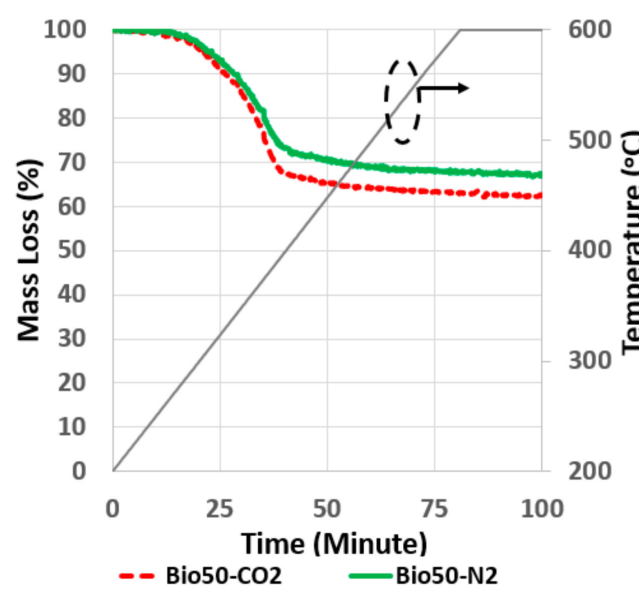

(B)

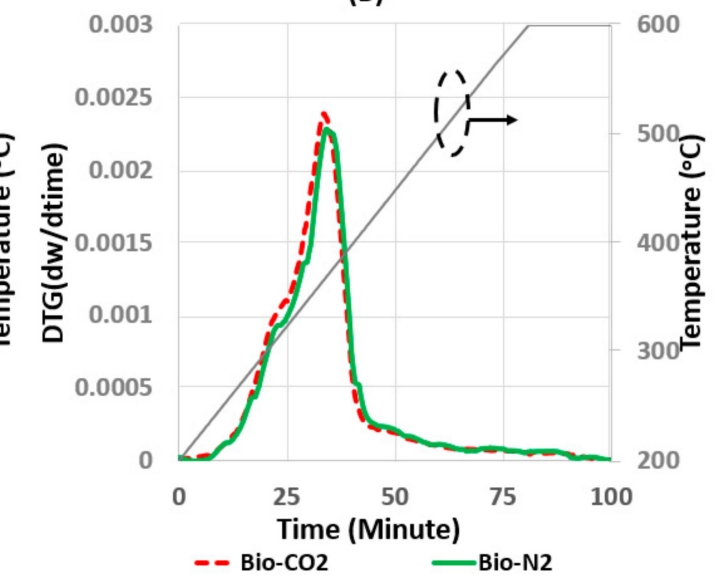

(D)

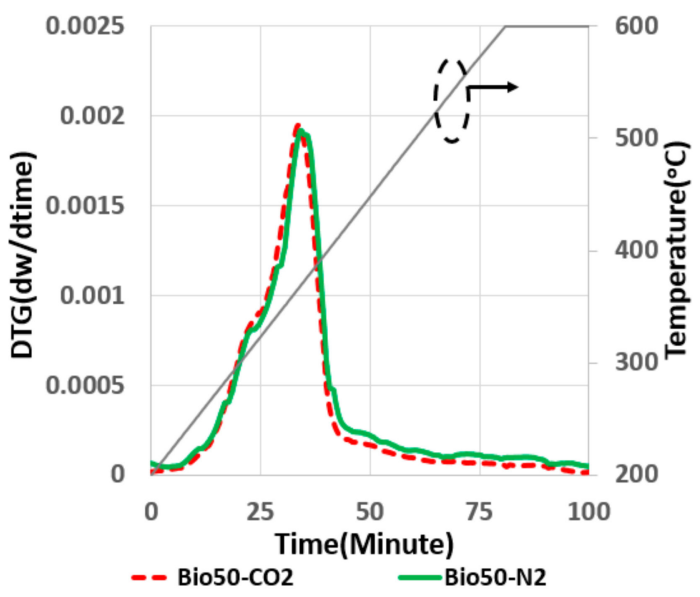

Figure 1. Thermogravimetric analysis (TGA) mass changes $(\mathbf{A}, \mathbf{C})$, and DTG curves $(\mathbf{B}, \mathbf{D})$ of Bio and Bio50. Conversion under $\mathrm{N}_{2}$ and $\mathrm{CO}_{2}$ at $600^{\circ} \mathrm{C}$.

Observation from differential thermogravimetric DTG curves of Bio pyrolysis and gasification in Figure 1B presents minor discrepancy, peak shifts, and peak height changes.

In the case of Bio50, the same outcome with a minor effect of injected gas on volatile removal is recorded, while lower total amount of mass loss (wt.\%) in Bio50- $\mathrm{N}_{2}$ and Bio50- $\mathrm{CO}_{2}$ is expected due to the addition of thermally stable salt. $[\mathrm{LiNaK}]_{2}\left(\mathrm{CO}_{3}\right)$ has an inhibitive impact on biogas emission from both Bio50- $\mathrm{N}_{2}$ and Bio50- $\mathrm{CO}_{2}$, which is in agreement with our previous works $[19,48]$. In untreated Bio- $\mathrm{CO}_{2}$, total mass loss was recorded at 86 wt.\%, and after modifying mass loss of $\mathrm{Bio} 50-\mathrm{CO}_{2}$ (excluding weight of carbonate) devolatilization of the treated sample was $6 \mathrm{wt}$ \% different with only 
$80 \mathrm{wt} . \%$ lost. Molten carbonate is fairly stable at $600{ }^{\circ} \mathrm{C}$ under both $\mathrm{N}_{2}$ and $\mathrm{CO}_{2}$ with minor weight loss (less than $2 \mathrm{wt} . \%$ ), but above $400{ }^{\circ} \mathrm{C}$ (when it transforms to liquid phase), the additive has still been shown to influence the biomass devolatilization mechanism, generating bubble-shaped carbonaceous particles and a porous structure of woody biomass [19].

Previous works $[39,48]$ suggest no interaction between carbonate and carbon at $600{ }^{\circ} \mathrm{C}$, which means carbonate gasification reaction will not take place at this temperature. In regard to this, the stability of carbonate and carbon/carbonate gasification is examined by investigating Char50 and the pure eutectic under both pyrolysis $\left(\mathrm{N}_{2}\right)$ and gasification $\left(\mathrm{CO}_{2}\right)$ conditions in Figure 2.

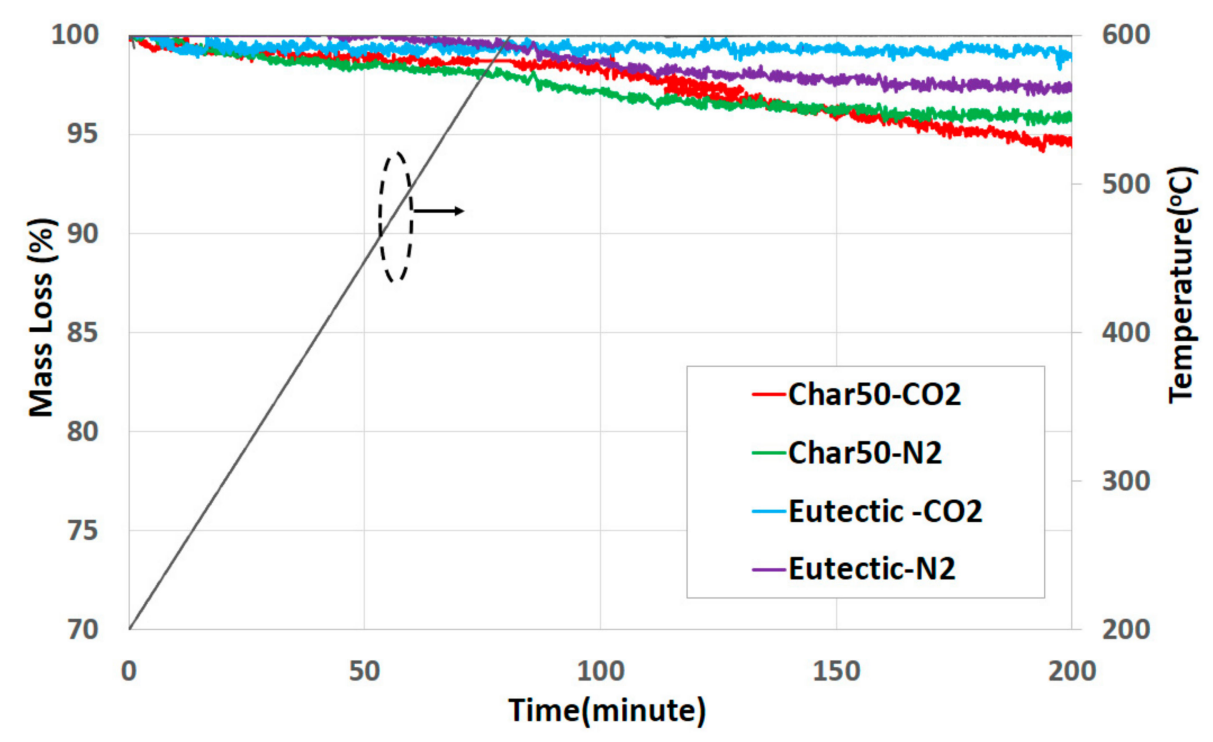

Figure 2. TGA mass changes Char50 decomposition and eutectic stability under $\mathrm{N}_{2}$ and $\mathrm{CO}_{2}$ at $600{ }^{\circ} \mathrm{C}$.

Figure 2 presents the mass loss of eutectic up to $600{ }^{\circ} \mathrm{C}$ under $\mathrm{N}_{2}$ (approximately $2 \mathrm{wt} . \%$ ) and $0 \%$ (negligible) under $\mathrm{CO}_{2}$, and both Char50- $\mathrm{CO}_{2}$ and Char50- $\mathrm{N}_{2}$ show less than $5 \mathrm{wt} . \%$ mass loss to the end of isothermal test time $(2 \mathrm{~h})$. This outcome relates to plausible removal of any remaining volatiles in the prepared char and slight decomposition of molten carbonate.

To understand morphology of remnant char from Bio50- $\mathrm{CO}_{2}$, water washed sample (Section 2) SEM images are expressed in Figures 3 and 4. The overall view, with 100x magnification image in Figure 3, clearly recorded agglomerated particles with some ruptured shapes (highlighted with a yellow circle), which is in accordance with Bio50- $\mathrm{N}_{2}$ morphology (detailed images are available in [19] and SEM images of $\mathrm{N}_{2}$ are in supplementary data Figure S1). In Figure 4, by exploring more particles (A and $\mathrm{E}$ are two different particles) and higher magnification (B-D, $\mathrm{F}-\mathrm{H}$ ), the swollen particles and bubble structure were extensively sighted, along with some remaining salt residue (needle shape white minerals). This similarity of results confirmed the minor mass loss deviation of Bio50 conversion under $\mathrm{N}_{2}$ and $\mathrm{CO}_{2}$ from TGA analysis (Figure 1). The effect of swelling in carbon particles was also clearly observable, which was stated by other groups, mostly during the softening stage of coal [51,52] or biomass $[53,54]$ in different thermochemical conversion pathways. The presence of molten carbonate, specifically above its melting point $\left(600{ }^{\circ} \mathrm{C}\right)$, modifies condensable and non-condensable volatile emission and manipulates char structures. Previous observation of tar reduction and volatile evolution changes for treated biomass was carried out in an inert environment $\left(\mathrm{N}_{2}\right)$ of pyrolysis [19,48]; however, here, it is confirmed that this also occurs under $\mathrm{CO}_{2}$ with molten carbonate treatment up to $600{ }^{\circ} \mathrm{C}$. It can be concluded that molten carbonates impact on volatile release is independent of gaseous surroundings at working temperatures less than gasification (reaction-10) and vaporization. 


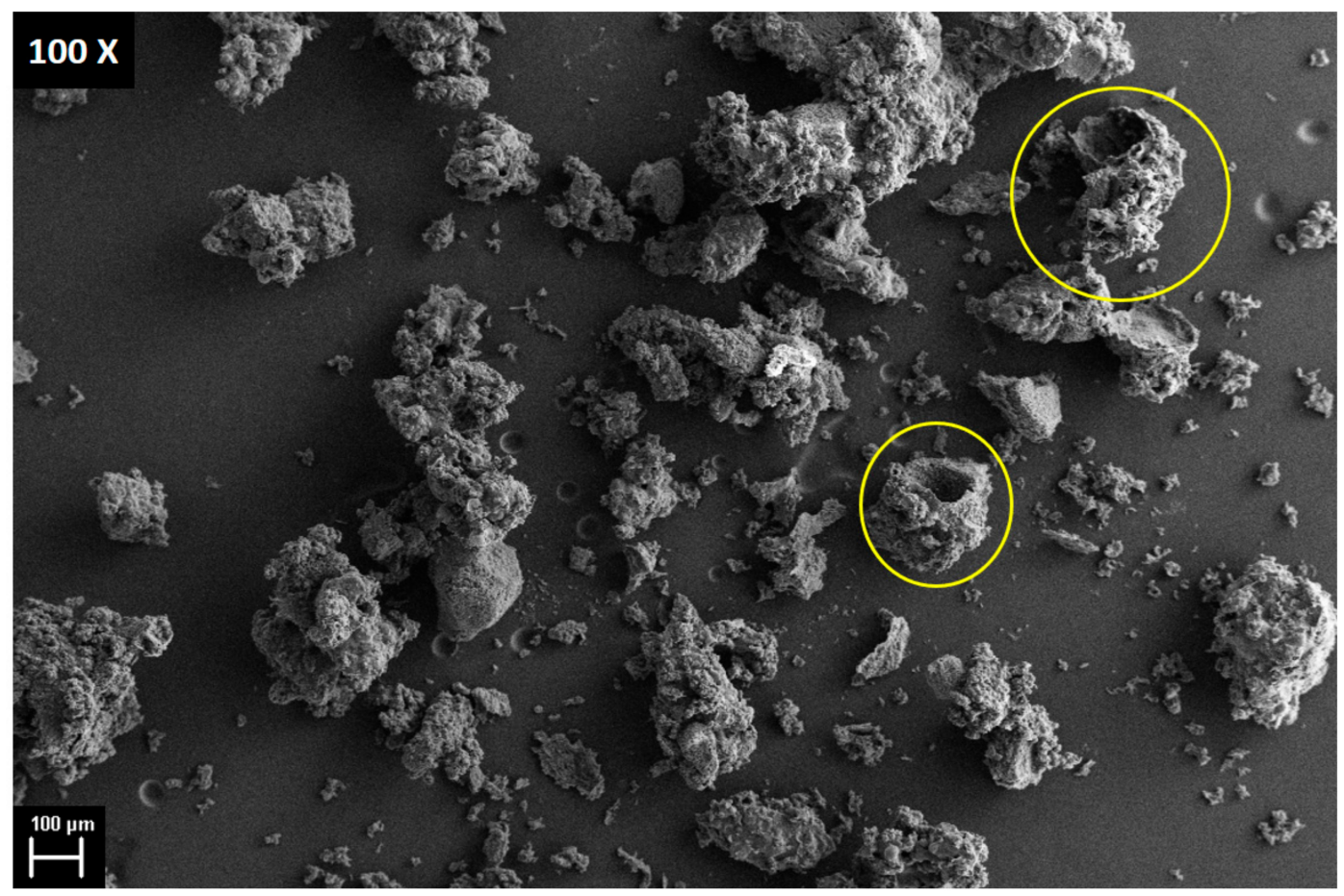

Figure 3. SEM image of particle distribution of washed Char from gasification of Bio50 at $600{ }^{\circ} \mathrm{C}$.

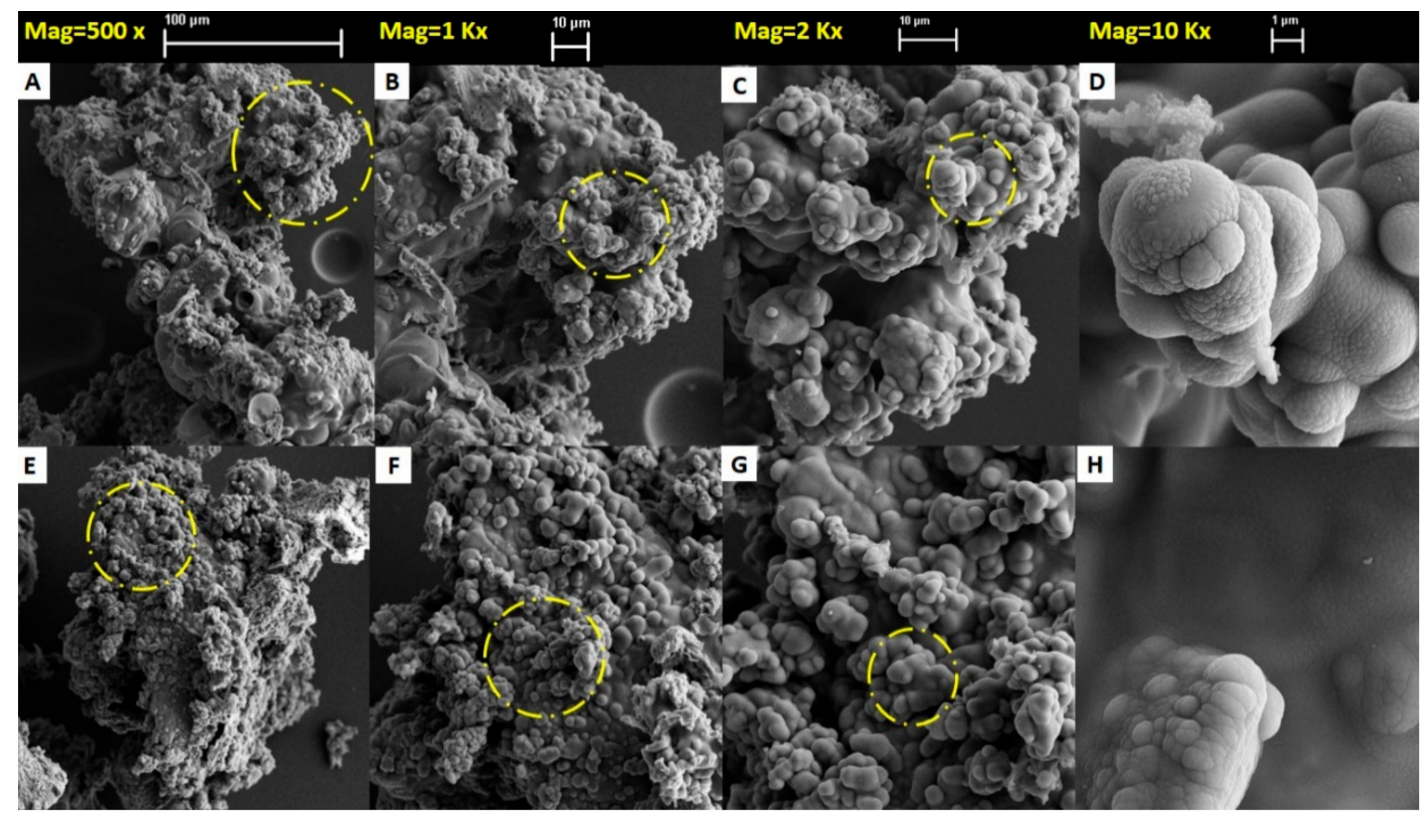

Figure 4. SEM image of particle distribution and surface morphology from Bio50-CO $\mathrm{CO}_{2}$ water washed at $600{ }^{\circ} \mathrm{C}(\mathbf{A}-\mathbf{D})$ Example particle at increasing magnification (E-H) additional particle at increasing magnification.

\subsection{Thermochemical Conversion under $\mathrm{N}_{2}$ vs. $\mathrm{CO}_{2}$ at High $\mathrm{HHT}\left(900^{\circ} \mathrm{C}\right)$}

By increasing the temperature to $900{ }^{\circ} \mathrm{C}$, the plots of mass loss versus temperature $\left({ }^{\circ} \mathrm{C}\right)$ are shown in Figures 5 and 6, where samples underwent drastic changes in mass. Initial results of biomass pyrolysis and gasification in Figure 5A,C,D displayed a similar trend to previous results from $600{ }^{\circ} \mathrm{C}$ (Figure 1) and, again, a slightly higher amount of mass loss under $\mathrm{CO}_{2}$. Under $\mathrm{N}_{2}$, biomass devolatilization was fully accomplished approximately at $600^{\circ} \mathrm{C}$ and no further mass loss was expected at the elevated temperature. However, under $\mathrm{CO}_{2}$ and above $\sim 750^{\circ} \mathrm{C}$, there was a second 
weight decrease and peak of the DTG curve (Figure 5C,D), potentially resulting from Boudouard gasification (reaction 5). In the case of biomass gasification, the set point of the Boudouard reaction was recorded at $\sim 735^{\circ} \mathrm{C}$, which can be seen in derivative curves based on temperature in graph $\mathrm{C}$ and time in graph D of Figure 5.

(A)

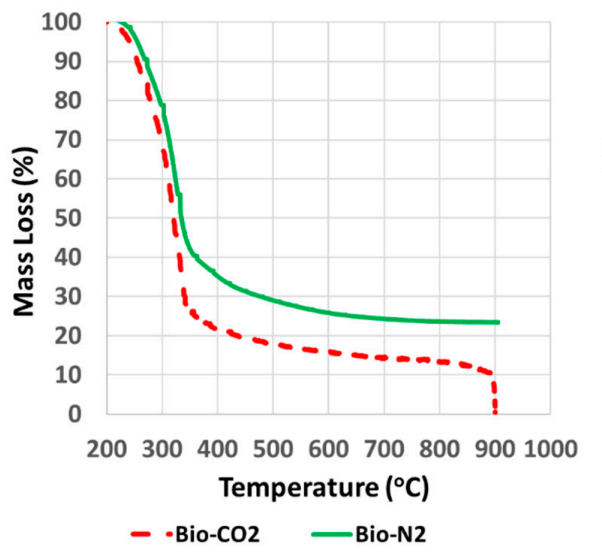

(B)

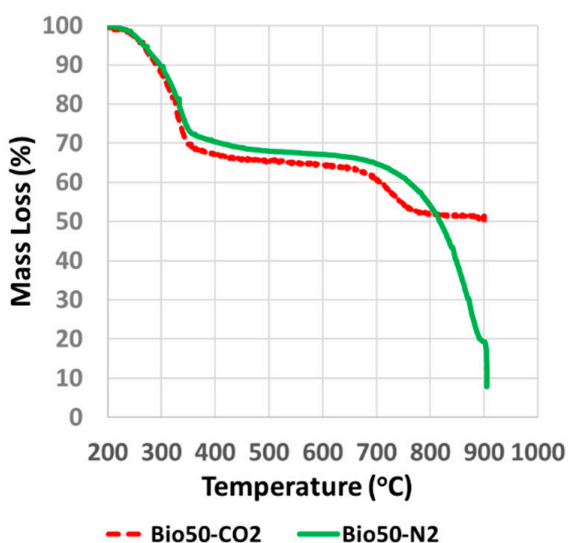

(c)

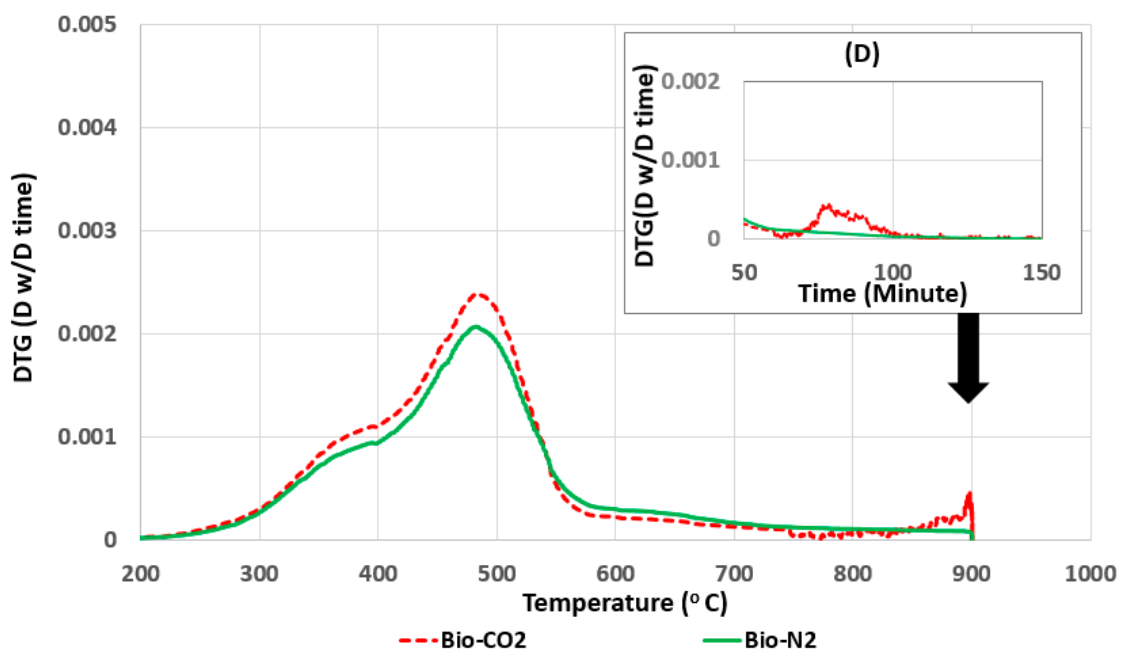

(E)

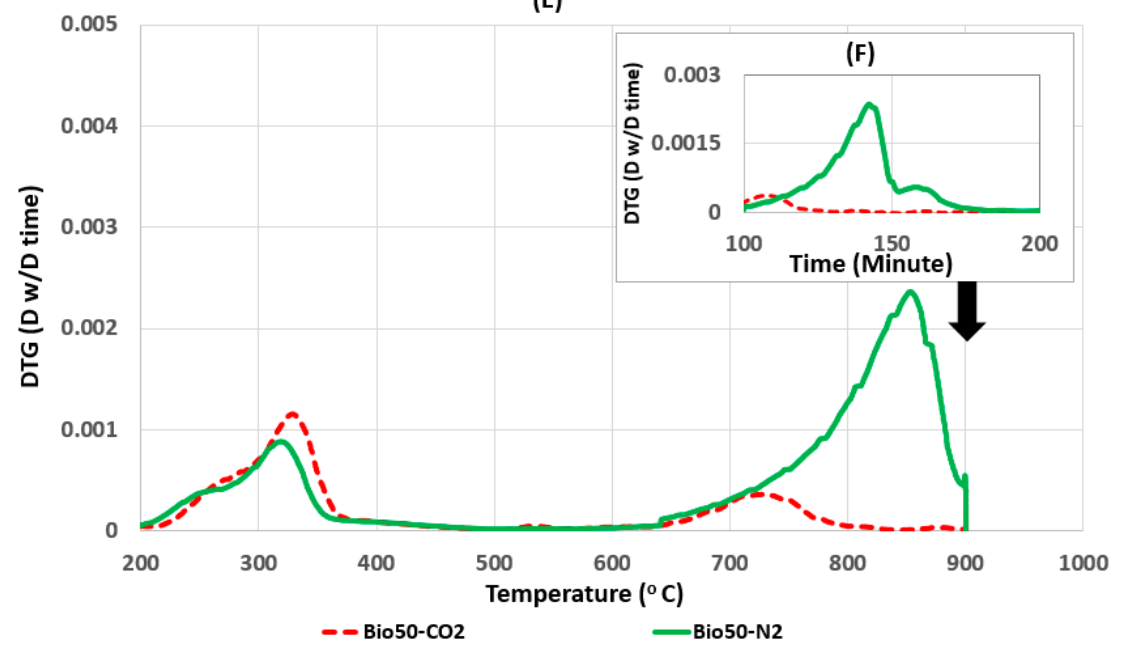

Figure 5. TGA mass changes (A,B) and DTG curves (C-F) of Bio and Bio50 thermochemical conversion under $\mathrm{N}_{2}$ and $\mathrm{CO}_{2}$ at $900{ }^{\circ} \mathrm{C}$. 
(A)

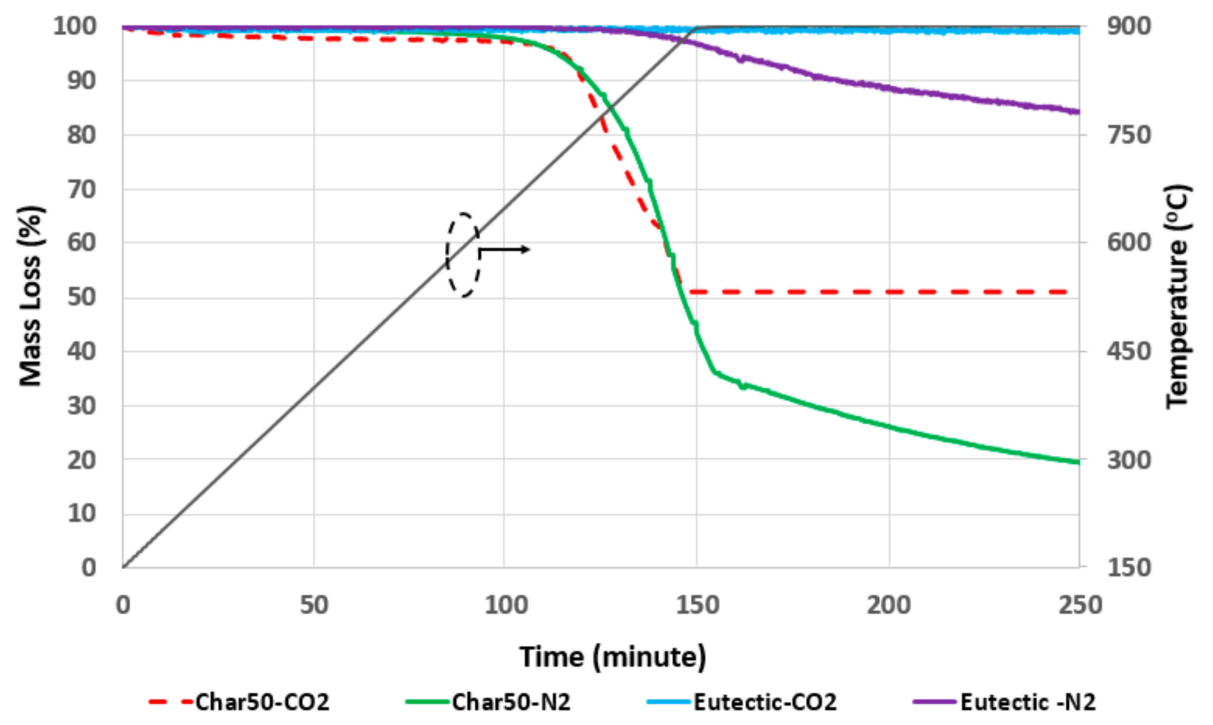

(B)

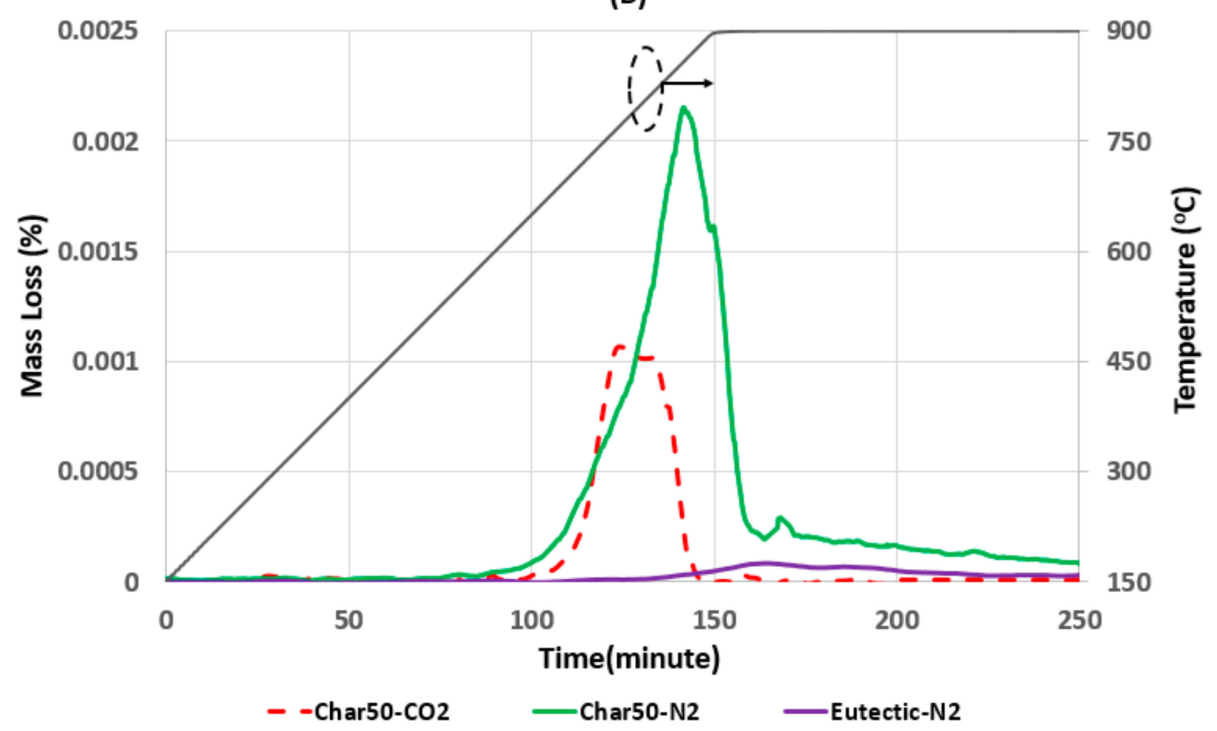

Figure 6. TGA mass changes (A) and DTG curve (B) of Char50 and eutectic. Stability under $\mathrm{N}_{2}$ and $\mathrm{CO}_{2}$ at $900{ }^{\circ} \mathrm{C}$.

For the next step, comparison of Bio50- $\mathrm{N}_{2}$ and Bio50- $\mathrm{CO}_{2}$ was investigated (Figure $5 \mathrm{~B}, \mathrm{E}, \mathrm{F}$ ), and for both conversion procedures, the impact of molten carbonate was profound.

In Figure $5 \mathrm{~B}$, presumably by passing the devolatilization stage $\left(<600{ }^{\circ} \mathrm{C}\right)$, we already had a mixture of solid char and molten carbonate in the system. Thus, a weight loss of Bio50- $\mathrm{N}_{2}$ above $750{ }^{\circ} \mathrm{C}$ (green line) is an indication of carbon/carbonate interaction (reaction-10) and molten carbonate decomposition (reaction-9), as well as possible vaporization. The starting point of this change was recorded at $660^{\circ} \mathrm{C}$ and continued during $2 \mathrm{~h}$ isothermal at $900{ }^{\circ} \mathrm{C}$.

On the other hand, in Bio50- $\mathrm{CO}_{2}$, eutectic is expected to be firmly unreactive (no mass loss originates from salts from either decomposition of vaporization, according to results in Figure 6) and Boudouard gasification is the expected reason for TGA mass loss or DTG peaks (Figure 5B,E,F). It is believed that carbonate decomposition (reaction-9) is thermodynamically less likely in this case; however, carbon/carbonate gasification (reaction-10) might be plausible, as well as dominant Boudouard gasification (reaction-5), where $\mathrm{CO}$ becomes the favored product. As it has been shown in 
the literature, alkali-metal carbonates catalyze the Boudouard reaction $[11,24,55,56]$, thus, there was a backshift in DTG by a primary onset at $640{ }^{\circ} \mathrm{C}$, which implied accelerated reaction- 5 in comparison with untreated Bio (onset at $\sim 735^{\circ} \mathrm{C}$ ). Figure $5 \mathrm{E}, \mathrm{F}$ enables us to distinguish peak differences of both Bio- $\mathrm{CO}_{2}$ and Bio- $\mathrm{N}_{2}$. As it is explained, in the case of $\mathrm{CO}_{2}$, there was an individual pathway of carbon gasification (reaction-5) that generated a single peak (red dashed in Figure 5E,F). This peak was smaller than the Bio- $\mathrm{N}_{2}$ mass loss, which was related to the amount of sample at $600{ }^{\circ} \mathrm{C}$. All tests started with biomass (not biochar), which, during devolatilization, lost almost $75 \mathrm{wt} . \%$ of its primary weight. Thus, by reaching to $700{ }^{\circ} \mathrm{C}$, only a small amount of carbon remained in the eutectic to react with $\mathrm{CO}_{2}$. This was in contrast with Bio50- $\mathrm{N}_{2}$, which would be expected to contain a similar amount of char, but follows a more complex mass loss from the transformation of both media still present (carbon and molten salts).

To elaborate on this phenomena, the reactivity of prepared and carbonate mixed char (preparation procedure explained in Section 2) under $\mathrm{CO}_{2}$ and $\mathrm{N}_{2}$ (named Char50- $\mathrm{CO}_{2}$ and Char50- $\mathrm{N}_{2}$ ) was examined, as well as the stability of $[\mathrm{LiNaK}]_{2}\left(\mathrm{CO}_{3}\right)$ up to $900{ }^{\circ} \mathrm{C}$ (Figure 6). As expected, eutectic stability under $\mathrm{CO}_{2}$ showed no mass loss, in contrast with almost $18 \mathrm{wt}$.\% degradation under $\mathrm{N}_{2}$, in line with our previous outcome for $\mathrm{N}_{2}$ gas atmospheres [19]. Vaporization of carbonate in this case was only observed to cause the TGA crucible to stick to the walls, suggesting vaporization and fusion of carbonate within the analysis equipment (as pictured in Figure S2 in supplementary data). This time, by loading the same amount of stabilized carbon-rich char for both treated pyrolysis and gasification, Char50- $\mathrm{CO}_{2}$ demonstrated almost $47 \mathrm{wt} . \%$ mass loss (from $640{ }^{\circ} \mathrm{C}$ to $880{ }^{\circ} \mathrm{C}$ ), and the DTG peak height could be seen to be higher than Bio50- $\mathrm{CO}_{2}$ (Figure $5 \mathrm{E}, \mathrm{F}$ ). Additionally, a decrease of weight continued for Char50- $\mathrm{N}_{2}$ to the end of the $2 \mathrm{~h}$ isothermal period $\left(900^{\circ} \mathrm{C}\right)$, in line with results of decomposition (reaction-9) and vaporization expected to occur for the pure eutectic. According to plotted data in Figures 5F and 6A,B, there were two steps of mass loss and two peaks in Bio50- $\mathrm{N}_{2}$ and Char50- $\mathrm{N}_{2}$. It was be expected that the first peak (before reaching $900{ }^{\circ} \mathrm{C}$ ) might originate from carbon/carbonate gasification, since this mass loss was not observed for the pure eutectic. However, in the presence of carbon particles, carbonate decomposition and vaporization must have also occurred, since the mass loss in this section exceeded the mass of carbon present ( $>50 \mathrm{wt} . \%)$ and continued further into the isothermal period. The mass loss of Char50- $\mathrm{N}_{2}$ represented a two-step mass loss, as shown in Figure 6A. It is suggested here that the major mass loss first experienced by the mixture was mostly a result of carbon catalyzed carbonate decomposition and vaporization. When the temperature stabilized the remaining carbonate particles, the carbon could then undergo further carbon/carbonate gasification (recation-4). To understand this, GC analysis of Bio50- $\mathrm{N}_{2}$ and $\mathrm{Bio50}-\mathrm{CO}_{2}$ is interpreted in Figure 7.

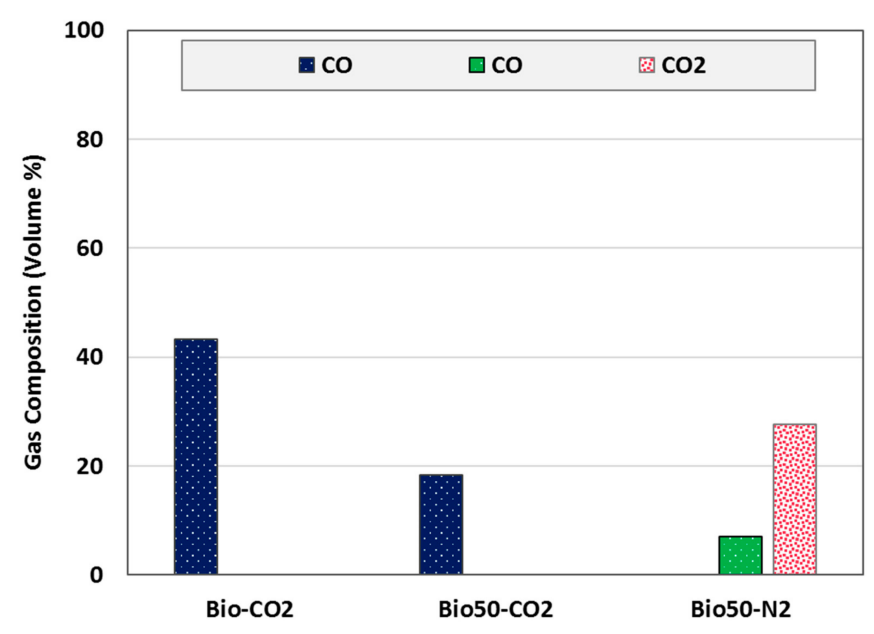

Figure 7. Volume \% of emitted $\mathrm{CO}$ and $\mathrm{CO}_{2}$ from different samples conversion under $\mathrm{N}_{2}$ and $\mathrm{CO}_{2}$ above $\sim 600{ }^{\circ} \mathrm{C}$. 
The amount of $\mathrm{CO}$ generated from Bio- $\mathrm{CO}_{2}$ appeared to be more than $\mathrm{Bio50}-\mathrm{CO}_{2}(\sim 24$ vol.\% difference), which is regarded a result of a lower amount of applied carbon in the treated sample.

Carbon/carbonate gasification took place under $\mathrm{N}_{2}$ and results in $\sim 7$ vol. $\%$ of the gaseous outlet CO. Production of $\sim 27 \mathrm{vol} \% \mathrm{CO}_{2}$ from Bio50- $\mathrm{N}_{2}$ supported the sharp peak of DTG and expressed a mass loss of TGA in Figures 5 and 6, seemingly as a circumstances of strong, likely carbon-enhanced carbonate decomposition (reaction-9). This is in agreement with previous intuition from McKee and Chatteriji [57], who investigated graphite conversion (treated with $\mathrm{Na}_{2} \mathrm{CO}_{3}$ at $600{ }^{\circ} \mathrm{C}$ ) in low $\mathrm{CO}_{2}$ environment, where results indicated enhanced carbonate decomposition. Peng et al. [44] applied post-test Energy Dispersive X-Ray Analysis EDX analysis and detected a higher amount of metal oxide formation under $\mathrm{N}_{2}$ carbothermal reduction of coal from $\mathrm{Li}-\mathrm{K}$ carbonate compared with $\mathrm{CO}_{2}$ (from 650 to $750{ }^{\circ} \mathrm{C}$ ). Physical vaporization of carbonate at this temperature is another plausible pathway that we witnessed during our experiments at $900{ }^{\circ} \mathrm{C}$, but is difficult to quantify (Figure S2, supplementary data). Additionally, as the major component of gaseous outlet was $\mathrm{CO}_{2}$ rather than $\mathrm{CO}$, it could be seen that the premier mass loss, as shown in Figure 5E,F and Figure 6B, of treated samples must relate to decomposition rather than gasification, which would result in much higher $\mathrm{CO}$ formation. Thus, the intricate mechanism of carbonate under $\mathrm{N}_{2}$ and in presence of carbon, underwent different steps from physical changes of salt (vaporization) to known and unknown extent of chemical reactions (such as decomposition and gasification), while in $\mathrm{C}_{2}$-rich atmosphere, Boudouard consumption (reaction-5) was catalyzed in the presence of otherwise stable and unreactive $[\mathrm{LiNaK}]_{2}\left(\mathrm{CO}_{3}\right)$.

\section{Discussion}

According to the described results in Section 3, it is essential to elaborate internal phenomena during treated biomass pyrolysis and gasification at a high temperature $\left(\sim 900^{\circ} \mathrm{C}\right)$. As it is shown in graphical illustration in Figure 8, the right side represents interaction between molecules when Bio50 undergoes $\mathrm{N}_{2}$ thermochemical conversion.

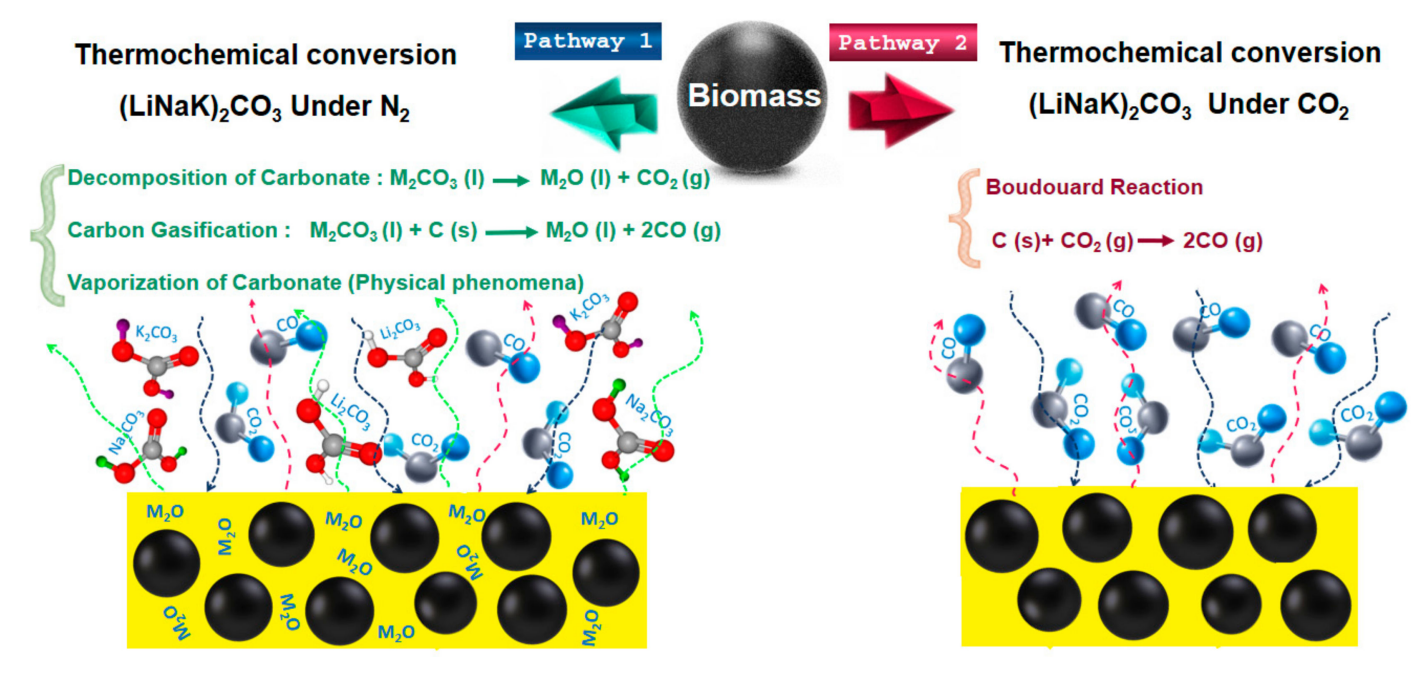

Figure 8. Graphical illustration of biomass thermochemical conversion in molten carbonate $\left([\mathrm{LiNaK}]_{2}(\mathrm{CO})_{3}\right.$ under $\mathrm{N}_{2}$ and $\mathrm{CO}_{2}$ at $900{ }^{\circ} \mathrm{C}$.

The complexity of various chemical reactions, such as carbon/carbonate gasification, molten carbonate decomposition, and physical phenomena, such as salt vaporization, registered a large mass loss in TGA (Figures 5 and 6). Above a temperature of $750^{\circ} \mathrm{C}$, all these reactions gradually took place, differentiating that each contribution was intricate. At first, because of a high amount of weight decrease in Bio50- $\mathrm{N}_{2}$, it was that assumed carbon/carbonate gasification was the main pathway of carbonaceous fuel consumption and a higher amount of $\mathrm{CO}$ generation should be measured by GC (Figure 7). However, the extent of mass loss and the amount of generated $\mathrm{CO}_{2}$ expressed molten 
carbonate decomposition as the dominant route, which appeared to be accelerated in the presence of carbon particles. Other groups have also reported carbon/carbonate gasification and carbonate decomposition [34,44,57]. Kopyscincki's group [22] studied $\mathrm{K}_{2} \mathrm{CO}_{3}$ reaction with carbon particles from acid washed coal under $\mathrm{N}_{2}$. According to their findings above $800{ }^{\circ} \mathrm{C}$ (close to $\mathrm{K}_{2} \mathrm{CO}_{3}$ melting point at $891^{\circ} \mathrm{C}$ ), cleavage of $\mathrm{K}$ and carbon complex supplied appropriate conditions for potassium vaporization from the surface of carbon. Since they applied acid-washed coal and a single solid salt, they assumed they generated $\mathrm{CO}$ as the dominant gas from carbon $/ \mathrm{K}_{2} \mathrm{CO}_{3}$ gasification. In our work, because the ternary eutectic had a lower melting point $\left(\sim 400^{\circ} \mathrm{C}\right)$ than potassium carbonate $\left(891^{\circ} \mathrm{C}\right)$, vaporization of salts at $900{ }^{\circ} \mathrm{C}$ was expected to be more important (which was frequently sighted during experiments (Figure S2)). Therefore, ternary carbonate decomposition and vaporization were dominant over carbon/carbonate gasification. Although most of the available researches are limited to single or binary carbonate gasification, Glenn et al. [39] inspected interaction between coal particles and ternary molten carbonate $\left(\mathrm{Li}_{2} \mathrm{CO}_{3}, \mathrm{Na}_{2} \mathrm{CO}_{3}\right.$, and $\mathrm{K}_{2} \mathrm{CO}_{3}$ (43.5: 31.5: $25 \mathrm{~mol} \%$, respectively)) up to $800{ }^{\circ} \mathrm{C}$. The phenomena of coal/carbonate reaction under $\mathrm{N}_{2}$ and $\mathrm{CO}_{2}$ was in accordance with our outcome. Previously, in the absence of GC data, the suggested reaction mechanism was carbonate gasification under $\mathrm{N}_{2}$, as well as enhancing the Boudouard reaction when the gaseous injected switched to $\mathrm{CO}_{2}$ at $800^{\circ} \mathrm{C}$.

Overall, GC analysis of this work proves that carbon/carbonate is the weaker chemical interaction compared to decomposition and vaporization of liquid carbonate (ternary eutectic). However, to separate and measure the exact amount of salt vaporization (physical phenomena) from salt decomposition (chemical reaction) or any other possible pathway for further mass loss under inert environment, additional research into a highly equipped set up would be required.

The left pathway of Figure 8 demonstrates the Boudouard reaction, which is the dominant mechanism of mass loss at $900{ }^{\circ} \mathrm{C}$ under $\mathrm{CO}_{2}$, where the gas consumes carbon particles in the presence of stable molten carbonate. Molten carbonate has no decomposition or vaporization under $\mathrm{CO}_{2}$ [35] and is well known to accelerate the reverse Boudouard reaction $[3,23,40,55,58]$. The outcome of this work (Figures 5 and 6) also demonstrated improvement of $\mathrm{CO}_{2}$ gasification onset temperature from $\sim 735^{\circ} \mathrm{C}$ in untreated biomass to $\sim 640{ }^{\circ} \mathrm{C}$ for Bio50- $\mathrm{CO}_{2}$, as the circumstance of the carbonate catalytic effect with additional possibility of carbonate gasification increased observed mass loss.

The beneficial output of this work gives better understanding of carbonate performance and properties in various atmospheres and temperatures, which is applicable in different technologies, apart from biomass thermochemical conversion, such as solar thermal plants, fuel cells, and the direct carbon fuel cell.

\section{Conclusions}

The interaction of biomass and carbonate $\left([\mathrm{LiNaK}]_{2}(\mathrm{CO})_{3}\right)$ was investigated under $\mathrm{N}_{2}$ and $\mathrm{CO}_{2}$ at two different temperatures $\left(600^{\circ} \mathrm{C}\right.$ and $\left.900^{\circ} \mathrm{C}\right)$. Results from $600^{\circ} \mathrm{C}$ demonstrated suppressing of raw biomass devolatilization in the presence of molten carbonate, regardless of carrier gas types, and showed a slight increase in mass loss observed for $\mathrm{CO}_{2}$ atmospheres. The phenomena of swelling and bubble-shaped particles of remnant char from Bio50- $\mathrm{CO}_{2}$ was observed, which are the results of less devolatilization compared with Bio- $\mathrm{CO}_{2}$ (with $6 \mathrm{wt} . \%$ deviation in weight decrease) and a possible effect of carbonate in tar reduction. Experiments at a high temperature $\left(900^{\circ} \mathrm{C}\right)$ established the stability of carbonate under $\mathrm{CO}_{2}$ and demonstrated a reduction in starting temperature for the onset of Boudoard gasification $\left(\sim 640^{\circ} \mathrm{C}\right)$. However, under $\mathrm{N}_{2}$, the system was exposed to complex concurrent chemical reactions and physical vaporization phenomena with a number of synergistic reaction pathways observed. In the presence of carbon particles, molten carbonate decomposed more and generated more than three times the amount of $\mathrm{CO}_{2}$ in GC analysis compared to $\mathrm{CO}$. This result demonstrates the dominant pathway of decomposition and vaporization under nitrogen in comparison with carbon/carbonate gasification. 
Supplementary Materials: The following are available online at http://www.mdpi.com/1996-1073/13/20/5395/s1, Figure S1: SEM image of particle distribution and surface morphology from Bio50- $\mathrm{N}_{2}$ water washed char at $600{ }^{\circ} \mathrm{C}$, Figure S2: Vaporization of $\mathrm{LiNaK}_{2}\left(\mathrm{CO}_{3}\right)$ under $\mathrm{N}_{2}$ at $900{ }^{\circ} \mathrm{C}$ inside TGA column. Covers crucible, hookers and other sections.

Author Contributions: Conceptualization, T.J. and J.A.; methodology, T.J. and J.A.; formal analysis, T.J. and J.A.; writing—original draft preparation, T.J.; writing—review and editing, J.A. and B.M.; supervision, J.A. and B.M. All authors have read and agreed to the published version of the manuscript.

Funding: This research received no external funding.

Conflicts of Interest: The authors declare no conflict of interest.

\section{References}

1. Basu, P. Biomass Gasification, Pyrolysis and Torrefaction: Practical Design and Theory; Elsevier Science: Amsterdam, The Netherlands, 2013.

2. Lahijani, P.; Mohammadi, M.; Zainal, Z.A.; Mohamed, A. Advances in $\mathrm{CO}_{2}$ gasification reactivity of biomass char through utilization of radio frequency irradiation. Energy 2015, 93, 976-983. [CrossRef]

3. Lahijani, P.; Mohammadi, M. Catalytic Effect of Metal Species on Enhancement of $\mathrm{CO}_{2}$ Gasification Reactivity of Biomass Char. Int. J. Eng. 2015, 28, 1251-1256.

4. Nunes, L.; Matias, J.; Catalão, J. Biomass combustion systems: A review on the physical and chemical properties of the ashes. Renew. Sustain. Energy Rev. 2016, 53, 235-242. [CrossRef]

5. Yuan, P.; Wang, J.; Pan, Y.; Shen, B.; Wu, C. Review of biochar for the management of contaminated soil: Preparation, application and prospect. Sci. Total. Environ. 2019, 659, 473-490. [CrossRef] [PubMed]

6. Chhiti, Y.; Ouladsine, R.; Sahibeddine, A.; Bensitel, M. Catalytic effect of ash on bio-oil thermal conversion. Moroc. J. Chem. 2016, 4, 584-591.

7. Jalalabadi, T.; Li, C.; Yi, H.; Lee, D. A TGA study of $\mathrm{CO}_{2}$ gasification reaction of various types of coal and biomass. J. Mech. Sci. Technol. 2016, 30, 3275-3281. [CrossRef]

8. Wang, L.; Li, T.; Vaárhegyi, G.; Skreiberg, Ø.; Løvås, T. $\mathrm{CO}_{2}$ Gasification of Chars Prepared by Fast and Slow Pyrolysis from Wood and Forest Residue: A Kinetic Study. Energy Fuels 2018, 32, 588-597. [CrossRef]

9. Russell, S.H.; Turrion-Gomez, J.L.; Meredith, W.; Langston, P.A.; Snape, C. Increased charcoal yield and production of lighter oils from the slow pyrolysis of biomass. J. Anal. Appl. Pyrolysis 2017, 124, 536-541. [CrossRef]

10. Azwar, E.; Mahari, W.A.W.; Chuah, J.H.; Vo, D.V.N.; Ma, N.L.; Lam, W.H.; Lam, S.S. Transformation of biomass into carbon nanofiber for supercapacitor application-A review. Int. J. Hydrog. Energy 2018, 43, 20811-20821. [CrossRef]

11. Chhiti, Y.; Kemiha, M. Thermal conversion of biomass, pyrolysis and gasification. Int. J. Eng. Sci. (IJES) 2013, 2, 75-85.

12. Belgaum, V. Tar formation, Reduction and Technology of Tar during Biomass Gasification/Pyrolysis-An Overview. Int. J. Eng. Res. Technol. 2017, 6. [CrossRef]

13. Sharma, R.K.; Wooten, J.B.; Baliga, V.L.; Lin, X.; Chan, W.G.; Hajaligol, M.R. Characterization of chars from pyrolysis of lignin. Fuel 2004, 83, 1469-1482. [CrossRef]

14. Menon, V.; Rao, M. Trends in bioconversion of lignocellulose: Biofuels, platform chemicals \& biorefinery concept. Prog. Energy Combust. Sci. 2012, 38, 522-550. [CrossRef]

15. Masnadi, M.S.; Grace, J.R.; Bi, X.T.; Lim, C.J.; Ellis, N. From fossil fuels towards renewables: Inhibitory and catalytic effects on carbon thermochemical conversion during co-gasification of biomass with fossil fuels. Appl. Energy 2015, 140, 196-209. [CrossRef]

16. Gonzaález, J.F.; Romaán, S.; Gonzaález-Garcila, C.M.; Nabais, J.M.V.; Ortiz, A.L. Porosity Development in Activated Carbons Prepared from Walnut Shells by Carbon Dioxide or Steam Activation. Ind. Eng. Chem. Res. 2009, 48, 7474-7481. [CrossRef]

17. Dong, S.; He, X.; Zhang, H.; Xie, X.; Yu, M.; Yu, C.; Xiao, N.; Qiu, J. Surface modification of biomass-derived hard carbon by grafting porous carbon nanosheets for high-performance supercapacitors. J. Mater. Chem. A 2018, 6, 15954-15960. [CrossRef]

18. Luo, K.; Zhang, C.; Zhu, S.; Bai, Y.; Li, F. Tar formation during coal pyrolysis under $\mathrm{N} 2$ and $\mathrm{CO}_{2}$ atmospheres at elevated pressures. J. Anal. Appl. Pyrolysis 2016, 118, 130-135. [CrossRef] 
19. Jalalabadi, T.; Glenn, M.; Tremain, P.; Moghtaderi, B.; Donne, S.W.; Allen, J. Modification of Biochar Formation during Slow Pyrolysis in the Presence of Alkali Metal Carbonate Additives. Energy Fuels 2019, 33, 11235-11245. [CrossRef]

20. Umeki, K.; Häggström, G.; Bach-Oller, A.; Kirtania, K.; Furusjö, E. Reduction of Tar and Soot Formation from Entrained-Flow Gasification of Woody Biomass by Alkali Impregnation. Energy Fuels 2017, 31, 5104-5110. [CrossRef]

21. Hayashi, J.; Kazehaya, A.; Muroyama, K.; Watkinson, A. Preparation of activated carbon from lignin by chemical activation. Carbon 2000, 38, 1873-1878. [CrossRef]

22. Kopyscinski, J.; Rahman, M.; Gupta, R.; Mims, C.A.; Hill, J.M. $\mathrm{K}_{2} \mathrm{CO}_{3}$ catalyzed $\mathrm{CO}_{2}$ gasification of ash-free coal. Interactions of the catalyst with carbon in $\mathrm{N}_{2}$ and $\mathrm{CO}_{2}$ atmosphere. Fuel 2014,117,1181-1189. [CrossRef]

23. Bach-Oller, A.; Fursujo, E.; Umeki, K. Effect of potassium impregnation on the emission of tar and soot from biomass gasification. Energy Procedia 2019, 158, 619-624. [CrossRef]

24. Trubetskaya, A.; Larsen, F.H.; Shchukarev, A.; Ståhl, K.; Umeki, K. Potassium and soot interaction in fast biomass pyrolysis at high temperatures. Fuel 2018, 225, 89-94. [CrossRef]

25. Guo, J.; Lua, A.C. Textural and chemical characterizations of adsorbent prepared from palm shell by potassium hydroxide impregnation at different stages. J. Colloid Interface Sci. 2002, 254, 227-233. [CrossRef]

26. Raymundo-Piñero, E.; Azaïs, P.; Cacciaguerra, T.; Cazorla-Amorós, D.; Linares-Solano, A.; Béguin, F. KOH and $\mathrm{NaOH}$ activation mechanisms of multiwalled carbon nanotubes with different structural organisation. Carbon 2005, 43, 786-795. [CrossRef]

27. Prauchner, M.J.; Sapag, K.; Rodríguez-Reinoso, F. Tailoring biomass-based activated carbon for $\mathrm{CH}_{4}$ storage by combining chemical activation with $\mathrm{H}_{3} \mathrm{PO}_{4}$ or $\mathrm{ZnCl}_{2}$ and physical activation with $\mathrm{CO}_{2}$. Carbon 2016, 110, 138-147. [CrossRef]

28. Rutkowski, P. Pyrolysis of cellulose, xylan and lignin with the $\mathrm{K}_{2} \mathrm{CO}_{3}$ and $\mathrm{ZnCl}_{2}$ addition for bio-oil production. Fuel Process. Technol. 2011, 92, 517-522. [CrossRef]

29. Senneca, O.; Cerciello, F.; Heuer, S.; Ammendola, P. Slow pyrolysis of walnut shells in nitrogen and carbon dioxide. Fuel 2018, 225, 419-425. [CrossRef]

30. Fu, P.; Yi, W.; Li, Z.; Bai, X.; Wang, L. Evolution of char structural features during fast pyrolysis of corn straw with solid heat carriers in a novel V-shaped down tube reactor. Energy Convers. Manag. 2017, 149, 570-578. [CrossRef]

31. Kim, Y.; Oh, J.I.; Vithanage, M.; Park, Y.K.; Lee, J.; Kwon, E.E.; Ok, J.I. Modification of biochar properties using $\mathrm{CO}_{2}$. Chem. Eng. J. 2019, 372, 383-389. [CrossRef]

32. Kirtania, K.; Axelsson, J.; Matsakas, L.; Christakopoulos, P.; Umeki, K.; Furusjö, E. Kinetic study of catalytic gasification of wood char impregnated with different alkali salts. Energy 2017, 118, 1055-1065. [CrossRef]

33. Hathaway, B.J.; Davidson, J.H.; Kittelson, D.B. Solar Gasification of Biomass: Kinetics of Pyrolysis and Steam Gasification in Molten Salt. J. Sol. Energy Eng. 2011, 133, 021011. [CrossRef]

34. McKee, D.W. Catalytic effects of alkaline earth carbonates in the carbon-carbon dioxide reaction. Fuel 1980, 59, 308-314. [CrossRef]

35. Olivares, R.I.; Chen, C.; Wright, S. The Thermal Stability of Molten Lithium-Sodium-Potassium Carbonate and the Influence of Additives on the Melting Point. J. Sol. Energy Eng. 2012, 134, 041002. [CrossRef]

36. Glenn, M.J.; Allen, J.; Donne, S.W. Thermal Investigation of a Doped Alkali-Metal Carbonate Ternary Eutectic for Direct Carbon Fuel Cell Applications. Energy Fuels 2015, 29, 5423-5433. [CrossRef]

37. Glenn, M.; Mathan, B.; Islam, M.; Beyad, Y.; Allen, J.A.; Donne, S.W. Gas Atmosphere Effects Over the Anode Compartment of a Tubular Direct Carbon Fuel Cell Module. Energy Fuels 2019, 33, 7901-7907. [CrossRef]

38. Fereres, S.; Prieto, C.; Gavarrell, P.G.; Rodríguez, A.; Sánchez-Jiménez, P.E.; Pérez-Maqueda, L.A. Molten carbonate salts for advanced solar thermal energy power plants: Cover gas effect on fluid thermal stability. Sol. Energy Mater. Sol. Cells 2018, 188, 119-126. [CrossRef]

39. Glenn, M.J.; Allen, J.A.; Donne, S.W. Carbon Gasification from a Molten Carbonate Eutectic. Energy Technol. 2019, 7. [CrossRef]

40. Klopper, L.; Strydom, C.A.; Bunt, J.R. Influence of added potassium and sodium carbonates on $\mathrm{CO}_{2}$ reactivity of the char from a demineralized inertinite rich bituminous coal. J. Anal. Appl. Pyrolysis 2012, 96, 188-195. [CrossRef]

41. Mallick, D.; Mahanta, P.; Moholkar, V.S. Co-gasification of coal and biomass blends: Chemistry and engineering. Fuel 2017, 204, 106-128. [CrossRef] 
42. Hughes, M.A.; Allen, J.; Donne, S.W. The properties and performance of carbon produced through the electrochemical reduction of molten carbonate: A study based on step potential electrochemical spectroscopy. Electrochim. Acta 2018, 278, 340-351. [CrossRef]

43. Li, C.; Yi, H.; Jalalabadi, T.; Lee, D. Thermal decomposition of alkane hydrocarbons inside a porous Ni anode for fuel supply of direct carbon fuel cell: Effects of morphology and crystallinity of carbon. J. Power Sources 2015, 294, 284-291. [CrossRef]

44. Peng, F.; Li, Y.; Nash, P.; Cooper, J.F.; Parulekar, S.J.; Selman, J.R. Direct Carbon Fuel Cells—Wetting behavior of graphitic carbon in molten carbonate. Int. J. Hydrog. Energy 2016, 41, 18858-18871. [CrossRef]

45. Yoshida, S.; Matsunami, J.; Hosokawa, Y.; Yokota, O.; Tamaura, Y.; Kitamura, M. Coal/CO 2 Gasification System Using Molten Carbonate Salt for Solar/Fossil Energy Hybridization. Energy Fuels 1999, 13, 961-964. [CrossRef]

46. Yeboah, Y.D.; Xu, Y.; Sheth, A.; Godavarty, A.; Agrawal, P.K. Catalytic gasification of coal using eutectic salts: Identification of eutectics. Carbon 2003, 41, 203-214. [CrossRef]

47. Claes, P.; Moyaux, D.; Peeters, D. Solubility and solvation of carbon dioxide in the molten $\mathrm{Li}_{2} \mathrm{CO}_{3} / \mathrm{Na}_{2} \mathrm{CO}_{3} / \mathrm{K}_{2} \mathrm{CO}_{3}$ (43.5:31.5:25.0 mol-\%) eutectic mixture at 973 K I. Experimental part. Eur. J. Inorg. Chem. 1999, 1999, 583-588. [CrossRef]

48. Jalalabadi, T.; Drewery, M.; Tremain, P.; Wilkinson, J.; Moghtaderi, B.; Allen, J. The Impact of Carbonate Salts on Char and Gaseous Evolution during Slow Pyrolysis of Biomass, Cellulose, and Lignin. Sustain. Energy Fuels 2020. [CrossRef]

49. Nygård, H.S.; Olsen, E. Molten salt pyrolysis of milled beech wood using an electrostatic precipitator for oil collection. AIMS Energy 2015, 3, 284-296. [CrossRef]

50. Su, S.; Song, Y.; Wang, Y.; Li, T.; Hu, S.; Xiang, J.; Li, C.Z. Effects of $\mathrm{CO}_{2}$ and heating rate on the characteristics of chars prepared in $\mathrm{CO}_{2}$ and $\mathrm{N}_{2}$ atmospheres. Fuel 2015, 142, 243-249. [CrossRef]

51. Khan, M.R.; Jenkins, R.G. Influence of Added Calcium Compounds on Swelling, Plastic, and Pyrolysis Behavior of Coal Devolatilized at Elevated Pressures. Fuel 1986, 65, 1203-1208. [CrossRef]

52. Khan, M.; Jenkins, R.G. Swelling and plastic properties of coal devolatilized at elevated pressures: An examination of the influences of coal type. Fuel 1986, 65, 725-731. [CrossRef]

53. Riaza, J.; Ajmi, M.; Gibbins, J.; Chalmers, H. Ignition and combustion of single particles of coal and biomass under $\mathrm{O}_{2} / \mathrm{CO}_{2}$ atmospheres. In Proceedings of the 13th International Conference on Greenhouse Gas Control Technologies, Ghgt-13, Lausanne, Switzerland, 14-18 November 2016; 2017; Volume 114, pp. 6067-6073.

54. Riaza, J.; Khatami, R.; Levendis, Y.A.; Álvarez, L.; Gil, M.V.; Pevida, C.; Rubiera, F.; Pis, J.J. Combustion of single biomass particles in air and in oxy-fuel conditions. Biomass Bioenergy 2014, 64, 162-174. [CrossRef]

55. Perander, M.; DeMartini, N.; Brink, A.; Kramb, J.; Karlström, O.; Hemming, J.; Moilanen, A.; Konttinen, J.; Hupa, M. Catalytic effect of $\mathrm{Ca}$ and $\mathrm{K}$ on $\mathrm{CO}_{2}$ gasification of spruce wood char. Fuel 2015, 150, 464-472. [CrossRef]

56. Mims, C. Catalytic Gasification of Carbon: Fundamentals and Mechanism, in Fundamental Issues in Control of Carbon Gasification Reactivity; Springer: Berlin/Heidelberg, Germany, 1991; pp. 383-407.

57. McKee, D.; Chatterji, D. The catalytic behavior of alkali metal carbonates and oxides in graphite oxidation reactions. Carbon 1975, 13, 381-390. [CrossRef]

58. An, W.; Sun, X.; Jiao, Y.; Wang, S.; Wang, W.; Tadé, M.O.; Shao, Z.; Li, S.D.; Shuang, S. Inherently Catalyzed Boudouard Reaction of Bamboo Biochar for Solid Oxide Fuel Cells with Improved Performance. Energy Fuels 2018, 32, 4559-4568. [CrossRef]

Publisher's Note: MDPI stays neutral with regard to jurisdictional claims in published maps and institutional affiliations.

(C) 2020 by the authors. Licensee MDPI, Basel, Switzerland. This article is an open access article distributed under the terms and conditions of the Creative Commons Attribution (CC BY) license (http://creativecommons.org/licenses/by/4.0/). 